\title{
State Approaches to the System Benefits Charge
}

\author{
Jeffrey M. Fang
}

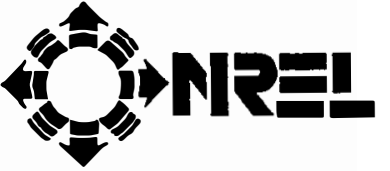

National Renewable Energy Laboratory 1617 Cole Boulevard Golden, Colorado 80401-3393

A national laboratory of the U.S. Department of Energy Managed by the Midwest Research Institute for the U.S. Department of Energy under Contract No. DE-AC36-83CH10093

Prepared under Task No. 0796.4603

July 1997 


\section{NOTICE}

This report was prepared as an account of work sponsored by an agency of the United States government. Neither the United States government nor any agency thereof, nor any of their employees, makes any warranty, express or implied, or assumes any legal liability or responsibility for the accuracy, completeness, or usefulness of any information, apparatus, product, or process disclosed, or represents that its use would not infringe privately owned rights. Reference herein to any specific commercial product, process, or service by trade name, trademark, manufacturer, or otherwise does not necessarily constitute or imply its endorsement, recommendation, or favoring by the United Slates government or any agency thereof. The views and opinions of authors expressed herein do not necessarily state or reflect those of the United States government or any agency thereof.

Available to DOE and DOE contractors from:

Office of Scientific and Technical Information (OSTI)

P.O. Box 62

Oak Ridge, TN 37831

Prices available by calling (423) 576-8401

Available to the public from:

National Technical Information Service (NTIS)

U.S. Department of Commerce

5285 Port Royal Road

Springfield, VA 22161

(703) 487-4650 


\section{Acknowledgements}

I am grateful for the funding provided by the National Renewable Energy Laboratory's (NREL) Sustainable Technology Energy Partnerships Initiative, Second Round (STEP-2). I also wish to acknowledge the assistance provided by Jim Galanis of the Office of Energy and Resource Planning, Utah Department of Natural Resources, in defining the scope of this study and in reviewing and commenting on an earlier draft of the report. Thanks are due the following state contacts who have provided information and/or commented on earlier drafts on their respective states: Ray T. Williamson, Arizona Corporation Commission; David Morse and Stuart Chaitkin, Califormia Public Utilities Commission, Division of Ratepayer Advocate; Theo MacGregor, Massachusetts Department of Public Utilities; Jim Gallagher and Martin Insogna, New York Public Service Commission; Mary Kilmarx, Rhode Island Public Utilities Commission; and Gary Mathis and Nancy Korda, Wisconsin Public Service Commission. Thanks are also due John Huddle, NREL, for the research assistance that he provided to the project, and to Kevin Porter and Paul Galen, also of NREL, for reviewing earlier versions of the report. 


\section{Contents}

Page

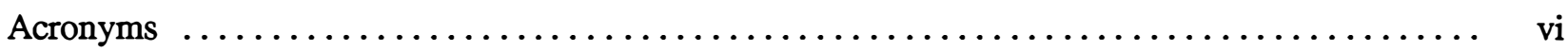

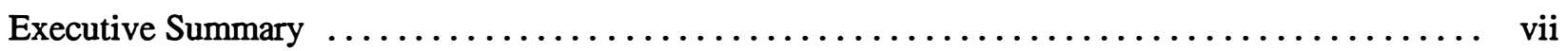

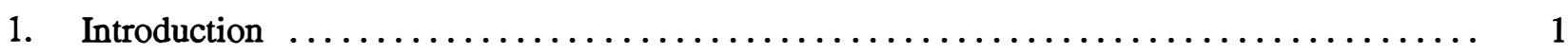

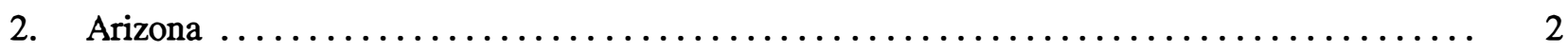

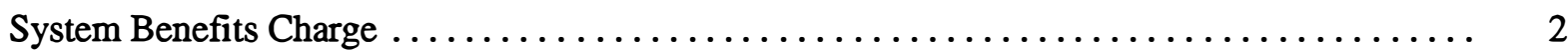

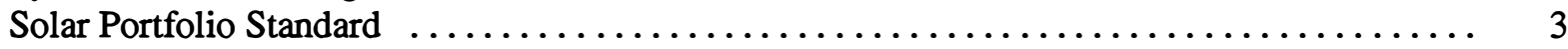

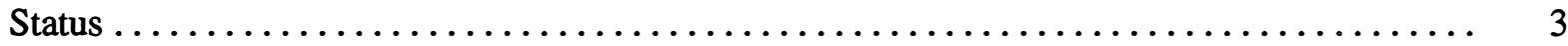

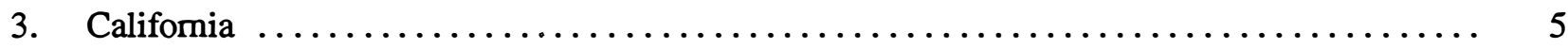

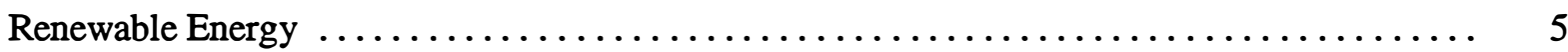

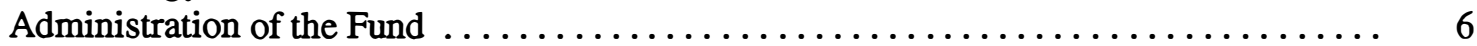

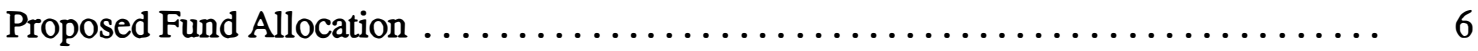

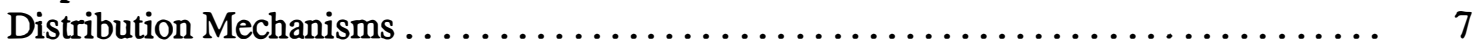

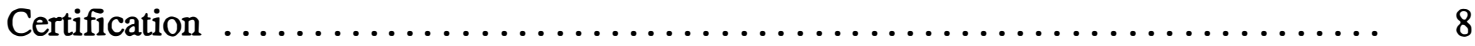

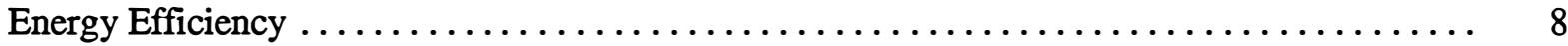

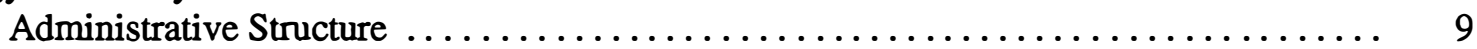

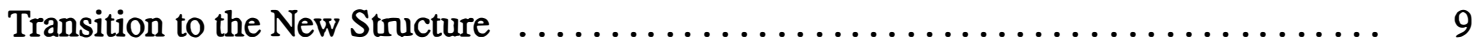

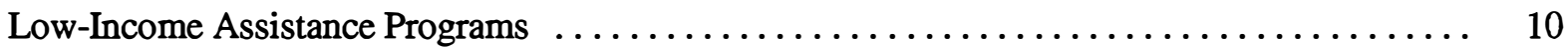

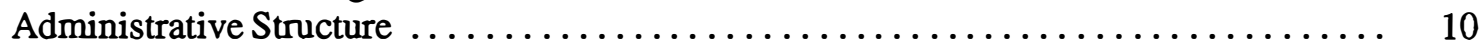

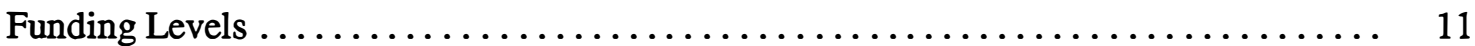

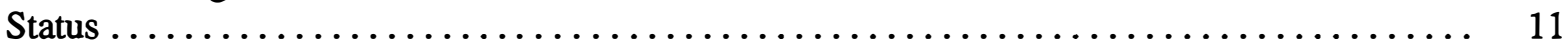

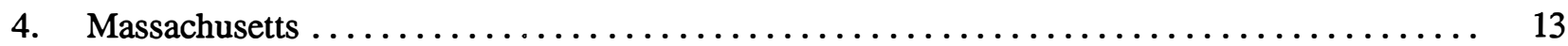

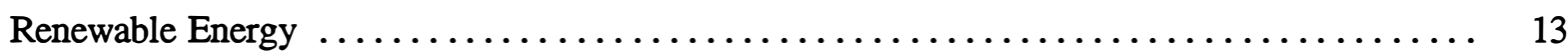

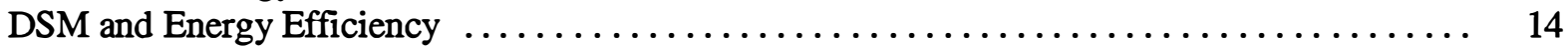

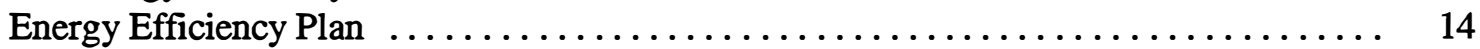

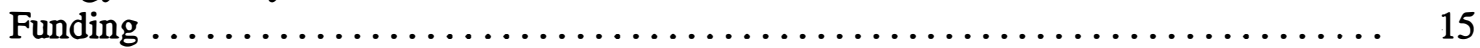

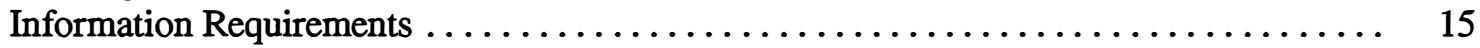

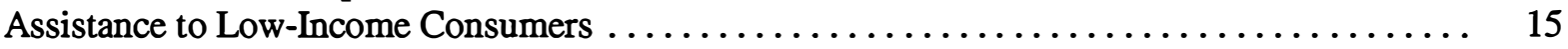

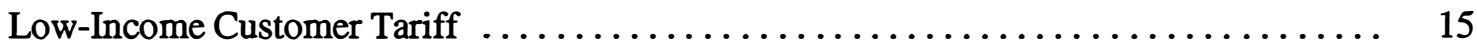

Weatherization Services to Low-Income Families . . . . . . . . . . . . . . 15

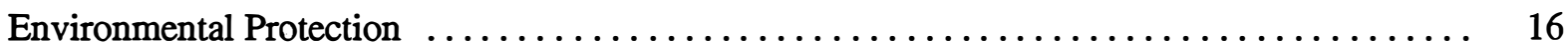

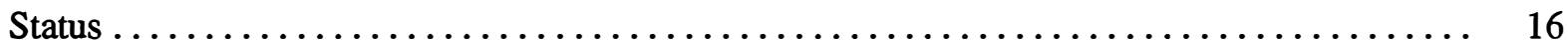

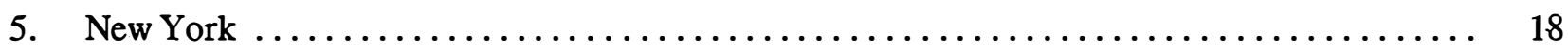

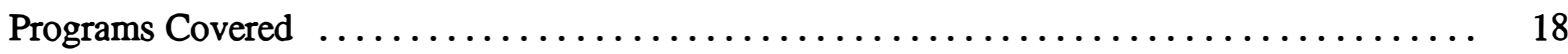

Energy Efficiency Services Programs . . . . . . . . . . . . . . . . . . . . 19

Research and Development Programs . . . . . . . . . . . . . . . . . . . . . . . 19

Low-Income Programs ....................................... 19 


\section{Contents (Concluded)}

$\underline{\text { Page }}$

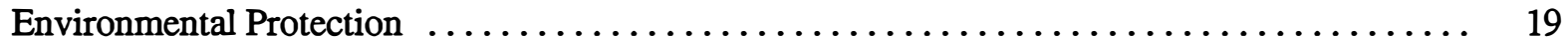

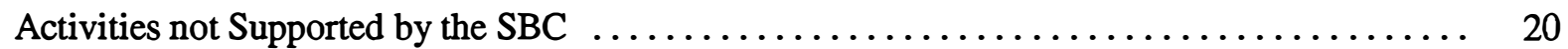

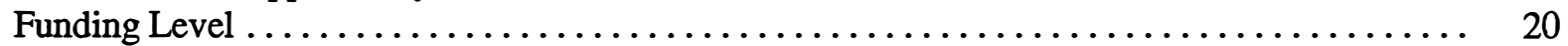

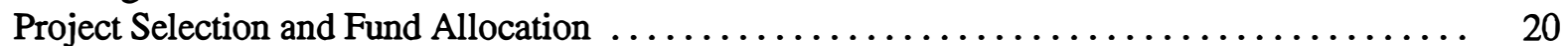

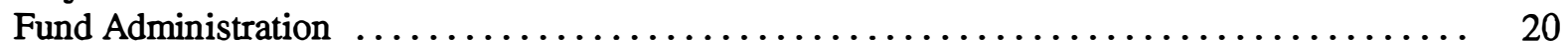

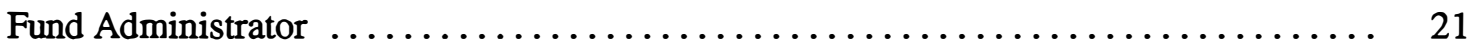

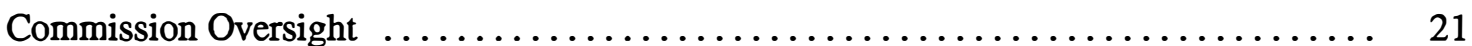

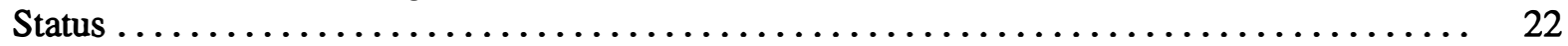

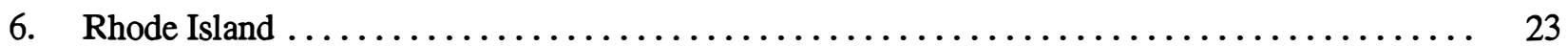

Demand-Side Management and Renewable Energy $\ldots \ldots \ldots \ldots \ldots \ldots \ldots \ldots \ldots \ldots \ldots \ldots \ldots$

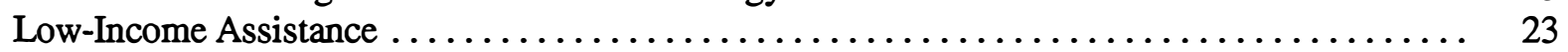

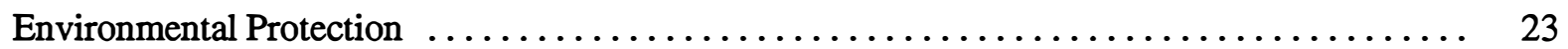

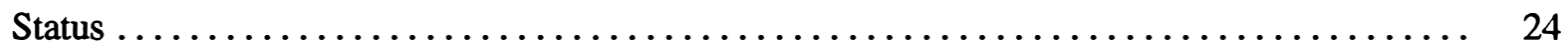

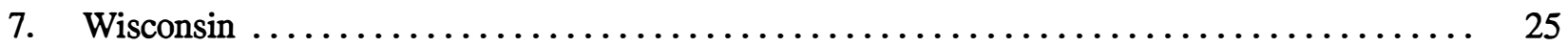

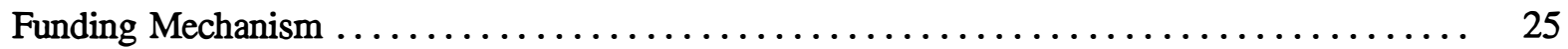

Energy Conservation, Renewables, and Environmental Research $\ldots \ldots \ldots \ldots \ldots \ldots \ldots \ldots . \ldots \ldots$

Energy and Environmental Public-Benefits Advisory Council ................ 26

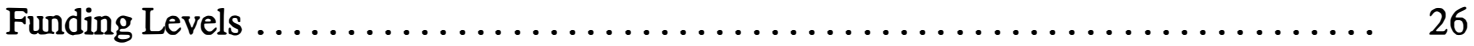

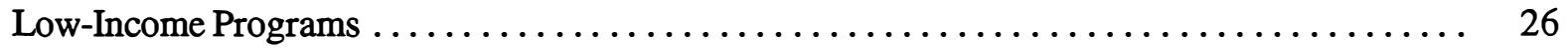

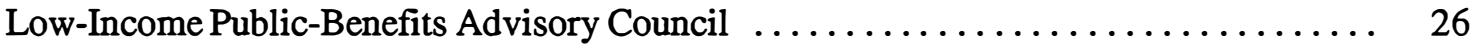

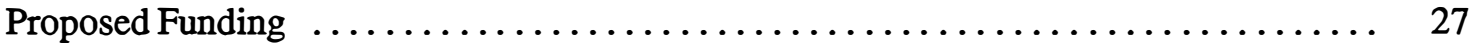

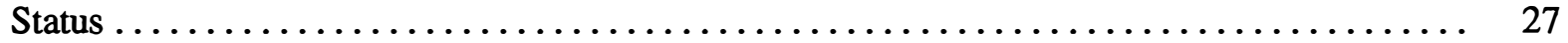

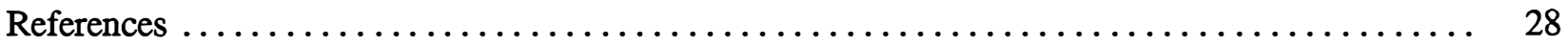

\section{List of Tables}

Page

1. Time-Differentiated Allocation of Renewable Energy Funds $\ldots \ldots \ldots \ldots \ldots \ldots \ldots \ldots \ldots$ 


\section{Acronyms}

$\begin{array}{ll}\text { AB } & \text { Assembly Bill (California) } \\ \text { ACC } & \text { Arizona Corporation Commission } \\ \text { Btu } & \text { British thermal units } \\ \text { CARE } & \text { California Alternative Rates for Energy } \\ \text { CEC } & \text { California Energy Commission } \\ \text { CPUC } & \text { California Public Utilities Commission } \\ \text { DPU } & \text { Department of Public Utilities (Massachusetts) } \\ \text { DSM } & \text { demand-side management } \\ \text { ESCO } & \text { energy service company } \\ \text { FERC } & \text { Federal Energy Regulatory Commission } \\ \text { IOU } & \text { investor-owned utility } \\ \text { kW } & \text { kilowatt } \\ \text { kWh } & \text { kilowatt-hours } \\ \text { MW } & \text { megawatt } \\ \text { MWh } & \text { megawatt-hours } \\ \text { NREL } & \text { National Renewable Energy Laboratory } \\ \text { NYPSC } & \text { New York Public Service Commission } \\ \text { OERP } & \text { Office of Energy and Resource Planning (Utah) } \\ \text { OTAG } & \text { Ozone Transport Assessment Group } \\ \text { PSC } & \text { Public Service Commission } \\ \text { PSCW } & \text { Public Service Commission of Wisconsin } \\ \text { R\&D } & \text { research and development } \\ \text { RD\&D } & \text { research, development, and demonstration } \\ \text { RFP } & \text { request for proposals } \\ \text { SBC } & \text { system benefits charge } \\ \text { SPS } & \text { Solar Portfolio Standard (Arizona) } \\ \text { STEP-2 } & \text { Sustainable Technology Energy Partnerships (2nd Round) } \\ \text { TAC } & \text { Technical Advisory Committee } \\ \text { transmission and distribution } \\ \text { Weatherization Assistance Program }\end{array}$




\section{Executive Summary}

This report documents the consideration and implementation of a non-bypassable system benefits charge (SBC) in six states through mid-May 1997. The SBC is being established to sustain important public-policy programs ${ }^{1}$ during the electric industry restructuring process. The states covered include Arizona, Califomia, Massachusetts, New York, Rhode Island, and Wisconsin.

This report was prepared for the Office of Energy and Resource Planning, Utah Department of Natural Resources, under the National Renewable Energy Laboratory's Sustainable Technology Energy Partnerships Initiative, Second Round (STEP-2). The purpose of the report is to provide decision makers in Utah, including the Utah Public Service Commission and the state legislature, with relevant information on the SBC for use in their deliberation on the matter.

The issues faced by the six states are the SBC in general; surcharge rate or funding levels; administrative structure and procedures; and actions, guidelines, and principles by program area. They are discussed in the following paragraphs.

\section{System Benefits Charge in General}

The general characteristics of the SBC are as follows:

- $\quad$ States are using the SBC to sustain public-policy programs while they make the transition from monopolies to competition in the electric industry restructuring process. Programs covered include energy efficiency, renewable energy, low-income assistance, environmental protection, and research and development (R\&D).

- The SBC is usually non-bypassable and imposed at the distribution level or the end-use level on a per kilowatt-hour $(\mathrm{kWh})$ basis. It is sometimes referred to as a wires charge or an access charge. It may also be in the form of an annual fee on providers of both gas and electric services. The last mechanism - an annual fee on service providers-is not imposed on the end users per se; hence, it is, strictly speaking, not an SBC. However, to the extent that such fees are shifted from the service providers to the end-use customers in the form of higher prices, it has the same characteristics as the SBC.

- $\quad$ The decision to use an SBC for public-policy programs may be made by the state legislature or by the regulatory commission. In some cases, the commission's proposals require final legislative actions prior to implementation.

\section{Surcharge Rate/Funding Levels}

Some states have set specific funding levels, in total dollar amounts, for either all public-purpose programs combined or for specific types of programs. In some instances, the funding levels from 1995 or 1996 were adopted. Other states have specified the surcharge rate in terms of mills $/ \mathrm{kWh}(\$ 0.001 / \mathrm{kWh})$.

- In California, the funding levels for different types of programs are set legislatively. For energy efficiency, the level is specified by company: $\$ 106$ million per year during the period 1998-2001 for Pacific Gas and Electric Company; \$32 million per year for San Diego Gas and Electric Company for

${ }^{1}$ Other terms such as" public-purpose programs" or "public-benefits programs" are also used in this report and in the literature. Specific program types are mentioned in the discussion in the text below. 
1998-2001; and $\$ 90$ million per year during the period 1998-2000, with a minimum of $\$ 50$ million in 2001, for Southem California Edison Company. For renewable energy, the level is set at $\$ 540$ million during the period 1998-2001 for all companies combined. For low-income assistance programs, the funding level is set at no less than the 1996 levels, based on assessment of customer needs.

- In Rhode Island, the funding level is set at a rate of $2.3 \mathrm{mills} / \mathrm{kWh}(\$ 0.0023 / \mathrm{kWh})$ for energy efficiency and renewable energy programs, starting on January 1, 1997. This amounts to more than $\$ 18$ million a year. In $1997, \$ 210,000$ was allocated for a study on renewable energy. In subsequent years, allocation to renewable energy is expected to increase.

- In Arizona, the funds are expected to be sufficient to cover all costs of the public-purpose programs currently approved by the commission. The methods for calculating the SBC are being developed via a workshop.

- In Massachusetts, the charge for renewable energy programs is being set at $1 \mathrm{mill} / \mathrm{kWh}(\$ 0.001 / \mathrm{kWh})$. The funding for energy efficiency and low-income assistance will be determined on a company-bycompany basis.

- In New York, the funding level is proposed at either $1 \mathrm{mill} / \mathrm{kWh}(\$ 0.001 / \mathrm{kWh})$ or the rate sufficient to support a utility's 1995 spending level for energy efficiency, public benefits R\&D, and low-income programs, whichever is lower. This would amount to almost $\$ 98$ million. Funding for environmental protection activities would be in addition to this total.

- In Wisconsin, the commission set the following specific annual funding levels in its proposal: $\$ 100$ million for energy conservation programs, $\$ 5$ million for renewable energy programs, $\$ 2$ million for environmental research, and $\$ 105$ million for low-income programs. These levels of funding are higher than in recent years.

\section{Administrative Structure and Procedures}

Four approaches to administering the system benefits funds and the programs that the funds will support have been considered or adopted: independent boards, a regulatory commission/existing agency assisted by advisory committees and/or administrators, distribution utilities, and a hybrid approach.

\section{Independent Boards}

In this approach, the regulatory commission appoints a separate decision-making board(s). This board allocates funds among different programs and issues a request for proposal (RFP) to hire one or more program administrator(s). The board may appoint a technical advisory committee to consult. The administrator in tum issues an RFP to hire contractors to implement specific projects. This structure is embodied in California's Independent Board for energy efficiency programs. It also underlies the Califomia Governing Board's approach to low-income assistance programs, with one difference. Under the Independent Board approach for energy efficiency programs, the administrators do not provide energy efficiency services or solutions directly; under the Goveming Board approach for low-income assistance programs, the program administrator can provide the required services to low-income families directly or through contractors.

\section{Regulatory Commission/Existing Agency Approach}

In this approach, the final decision-making authority rests with either the regulatory commission or an existing state agency. An advisory board or council may be established to assist in decision making. An administrator 
may be hired to administer the funds or programs, or the distribution utilities could administer the funds or programs with commission oversight. California, Massachusetts, New York, Rhode Island, and Wisconsin have proposed such an approach.

- In Califomia, the funds allocated for renewable energy and nontransmission- and distribution-related R\&D will be administered through the Califomia Energy Commission.

- Massachusetts will establish a renewables fund, with a collaborative process to develop the administrative details. In terms of energy efficiency and low-income assistance, Massachusetts will allow the utilities to administer the program with oversight from the Department of Public Utilities.

- In New York, one option considered by the commission staff is that the funds be managed by an administrator assisted by an advisory committee. Staff also proposed that a two-year implementation plan be developed through a formal proceeding, in which decisions will be made concerning the allocation of funds and projects to be funded.

- In Rhode Island, the commission will decide on how funds are allocated between renewable energy and energy efficiency. Utilities will implement energy efficiency and low-income assistance programs, assisted by the utility-specific collaboratives. A new statewide collaborative was initiated to work on renewable energy issues.

- In Wisconsin, it was proposed that an Energy and Environmental Public Benefits Advisory Council be established for a seven-year term. It would be organizationally attached to the Public Service Commission. In addition, a Low-Income Public Benefits Advisory Council is to be permanently established in the Department of Administration.

\section{Distribution Utilities}

In this approach, regulated distribution utilities continue to operate commission-approved programs and then file non-bypassable rates for recovering SBC costs for commission approval. This is embodied in the Arizona Corporation Commission's restructuring rules. This approach is likely to be adopted in the initial transition period to full retail competition. Because of the potential conflict of interest, this approach is likely to be phased out as decisions are made concerning alternative administration mechanisms.

\section{Hybrid Approach}

The hybrid approach would allow regulated distribution utilities to administer funds on programs with which they have comparative advantage while, at the same time, select a separate administrator to manage funds for statewide programs. In New York, the Commission staff is said to prefer the hybrid approach as the process of considering SBC proceeds toward a decision by the New York Public Service Commission.

\section{Actions, Guidelines, and Principles by Program Area}

The following paragraphs highlight some of the guidelines and principles that have been enunciated or proposed by the states with respect to energy efficiency, renewable energy, low-income assistance, and environmental protection. Some of these principles are embodied in the actions that have been taken so far. 


\section{Energy Efficiency}

The following are some principles concerning energy efficiency programs:

- Energy efficiency programs to be funded by an SBC should focus on efforts that would transform the market, promote the development of energy service markets, reduce market barriers, and educate consumers on energy efficiency matters.

- $\quad$ Programs supported by system benefits funds should create conditions in which competitive delivery of energy efficiency services would thrive.

- An effective consumer information and education component should be part of the program to enable consumers to make informed decisions about energy efficiency.

- System benefits funds collected for energy efficiency purposes should, in general, be expended in the geographical areas from which they are collected. However, a portion of such funds may be allocated to programs that are most cost effective when administered on a statewide basis.

\section{Renewable Energy}

Some of the actions, guidelines, and principles relating to renewable energy taken or pursued in the six states are noted below:

- $\quad$ All six states will use funds from an SBC or some competitively neutral funding mechanisms to support renewable energy. In New York, funding is limited to R\&D in renewable energy. In addition, Arizona has adopted a solar portfolio standard.

- $\quad$ Funds to support renewable energy may be allocated among different categories. California, for example, has established four categories: existing technologies, new technologies, emerging technologies, and customer-side assistance. Existing renewable technologies are further divided into three tiers: first tier, biomass and solar thermal; second tier, wind; third tier, geothermal, small hydro, digester gas, municipal solid waste, and landfill gas.

- The share of total funds to be allocated to each category can be differentiated according to opportunities and perceived importance. In California, the trends are as follows: existing technologies, declining shares over time; new technologies, increasing shares over time; emerging technologies, constant shares over time; customer-side assistance, constant shares over time.

- In California, the distribution of funds is based on production incentives per kilowatt-hour for existing and new technologies, with caps; a project-by-project approach through RFPs for emerging technologies, with caps; and consumption credit to customers, with caps.

- Certification is necessary in order for renewable energy suppliers and providers to receive payments from the system benefits funds. California has adopted a self-certification process for energy suppliers and providers to qualify for renewable funding from Assembly Bill 1890.

Consumer information and education should be part of the plan to fund the development of renewable energy technologies. Distribution utilities and energy providers should make all nonproprietary renewable energy information available to their customers to allow them to make informed decisions. 
- After an implementation period, the regulatory commission should review results of renewable funds operations and reevaluate the need to continue support of renewables funding and, if necessary, the level of funding.

\section{Low-Income Assistance Programs}

There are usually two types of low-income assistance programs: one with a rate discount and the other with low-income weatherization and energy efficiency elements.

- A rate discount program provides eligible customers with a certain level of discount on the rates they pay or helps eligible customers pay their energy bills. Initially, the discount rate may be set at the rate existing in 1996 or before the transition to full competition begins. In California, the program is called Califomia Altemative Rates for Energy, and the discount rate is $15 \%$. In Massachusetts and Rhode Island, the rate is at the level of the effective dates of the relevant commission order or legislation. In Arizona, it is at the level of existing programs approved by the commission. Wisconsin helps pay the energy bills of eligible customers. Any deficiency in revenues as a result of the assistance program will be recovered through the fees collected from the service providers.

- Low-income energy efficiency programs attempt to improve the energy efficiency of the low-income housing stock so as to lower customers' energy bills. This usually involves weatherization and energy conservation practices and measures. It is essential that low-income energy efficiency programs be coordinated with the general energy efficiency programs.

- Low-income energy assistance programs should create partnerships with various local and state programs or agencies such as the weatherization assistance program. The program should also leverage available state and federal funds for low-income assistance.

- There should be a consumer information and education program, including consultation on budgeting and credit counseling.

- Weatherization and energy efficiency programs should target diverse consumer groups, including customers with high energy bills and customers who could potentially benefit from large energy savings.

\section{Environmental Protection}

Environmental protection activities are usually considered in some way a part of the electric industry restructuring process. However, not all such activities are funded by an SBC. Because this study focuses on SBC issues, environmental protection outside of an SBC, such as in Califomia, is not covered in this report.

- In Arizona, environmental protection is covered by the SBC. The details of such requirements may be worked out in a workshop.

- Massachusetts will rely on efficient competition, customer choice, environmentally benign resource options, enhanced consumer information, support for and coordination with environmental regulation at the state and federal levels, and support for environmental comparability. Electric service suppliers and providers will be required to provide information on the sources and environmental impacts of electric power that will be supplied to consumers in Massachusetts. 
- New York will provide funding from an SBC on environmental protection activities approved by the commission that are not otherwise required by existing laws, including environmental monitoring and assessment.

- $\quad$ Rhode Island does not impose any specific requirements on existing power plants located within the state because of their already low emission levels. Out-of-state suppliers, however, are requested to work with environmental regulators in the states where their power plants are located to lower emissions of nitrogen oxides, sulfur dioxide, and particulates.

- In Wisconsin, environmental research is the responsibility of the proposed Energy and Environmental Public Benefits Advisory Board. The Public Service Commission of Wisconsin has proposed allocating $\$ 2$ million each year for this purpose. 


\section{Introduction}

The U.S. electric industry is undergoing fundamental changes in the transition from regulated monopolies to competitive markets that offer choices to customers. In light of this change, the question arises: How will major public-policy objectives, such as environmental protection, energy efficiency, renewable energy, and assistance to low-income customers, be sustained in this new competitive environment? Many mechanisms for meeting such public-policy objectives either have been or are being considered, including a nonbypassable system benefits charge (SBC), utility funds, state general funds, special funds, pollution tax, fees on energy service providers, renewable energy portfolio standard, green pricing and marketing, and pollution caps with tradable credits.

Many states are conducting formal inquiries into restructuring of the electric utility industry. In Utah, for example, the Utah Public Service Commission (PSC) began a proceeding on January 31, 1996, to investigate the changes in the structure of the electric utility industry and appropriate state regulatory responses to these changes. ${ }^{1}$ As a member of the Subcommittee on Social Benefits and Electric Utility Restructuring, the Utah Department of Natural Resources, Office of Energy and Resource Planning (OERP), is addressing the issues associated with public-policy programs and assisting the PSC in such efforts. The SBC is one of the alternative funding and implementation mechanisms currently being considered for addressing public-policy objectives. The National Renewable Energy Laboratory (NREL), as part of its Sustainable Technology Energy Partnerships Initiative, Second Round (STEP-2), is assisting OERP in a project on state approaches to the SBC.

The project investigated how states are implementing a non-bypassable SBC to fund energy efficiency, demand-side management, renewable energy, environmental programs, low-income energy assistance and weatherization, and other public-policy programs. ${ }^{2}$ This report documents the results of the project. The purpose of the report is to provide decision makers in Utah, including the Utah PSC and the state legislature, with relevant information on the SBC for use in their deliberations on the matter. The report describes the consideration and implementation of the SBC in six states that are in the process of implementing an SBC. The six states are Arizona, Califomia, Massachusetts, New York, Rhode Island, and Wisconsin. They are among the first states to consider and/or implement an SBC.

In the next six sections, each of the six states' specific considerations and decisions on the SBC through midMay 1997 are described in detail. Because the states included in this study are in different stages of implementation, the details of individual programs and practices vary substantially. The descriptions reflect such variations. In addition, some environmental programs are not specifically covered within the context of an SBC and are therefore not included in the descriptions.

${ }^{1}$ Utah Public Service Commission, Amended Order Establishing Investigative Docket, Docket No. 96-999-01, in the matter of the Cornmission's notice of inquiry: Changes in the structure of the electric utility industry and appropriate state regulatory responses. January 31, 1996.

${ }^{2}$ Other terms such as "public-purpose programs" or "public-benefits programs" are also used in this report and in the literature. 


\section{Arizona}

On December 26, 1996, the Arizona Corporation Commission (ACC) adopted its rules for restructuring the electricindustry. ${ }^{3}$ According to the rules, retail competition will be phased in beginning on January 1, 1999, with $20 \%$ of the market. This will increase to $50 \%$ in 2001 , reaching full retail competition by January 1 , 2003. Retail customers will be able to choose between standard-offer service, which is the traditional electric service they now have, and competitive services. In moving to restructure the electric industry, the ACC also sought to continue its past efforts to promote environmental protection, renewable resource development, increased energy efficiency, low-income customer assistance, and safe nuclear power plant decommissioning by using a non-bypassable system benefits charge. In addition, a solar portfolio standard (SPS) was adopted to encourage development of solar thermal electric and photovoltaic resources.

\section{System Benefits Charge}

The purpose of the system benefits charge is to ensure that certain public-benefits programs, such as those mentioned above, continue during the phase-in period. The ACC rules direct utilities to file non-bypassable rates or related mechanisms for recovering the costs of system benefits programs approved by the commission. Details of the rules include the following: ${ }^{4}$

- $\quad$ The rates shall be filed by December 31, 1997.

- $\quad$ Funds shall be sufficient to cover all costs of the system benefits programs currently approved by the commission. Total costs of such programs are prorated to standard-offer customers and customers seeking competitive services. Costs for system benefits programs allocated to standard-offer customers will be recovered through standard-offer rates. The non-bypassable SBC will be levied on customers seeking competitive services only. ${ }^{5}$

- The utilities can propose changes to the system benefits charge at any time for ACC review and approval.

- $\quad$ Adequate supporting documentation must be submitted with the filing of the SBC.

- The SBC can be collected only after approval by the commission, following public hearings on the issue.

- The commission has the option of combining its consideration of the SBC with considerations of standard-offer rates, unbundled services, stranded costs, and other Section R14-2-1606 issues.

- Workshops will be conducted to develop methods for calculating the SBC. A workshop should start no later than 90 days after adoption of the rule. A report from the workshops should be filed with the commission prior to November 1, 1997.

\footnotetext{
${ }^{3}$ Arizona Corporation Commission, Opinion and Order, Decision No. 59943, Docket No.
} U-0000-94-165, in the matter of the competition in the provision of electric services throughout the state of Arizona. December 26, 1996.

${ }^{4}$ ACC, Decision No. 59943, Section R14-2-1608.

${ }^{5}$ Berry, D., R.T. Williamson, and K. Clark, "Staff Discussion of the Proposed Rule on Electric Industry Restructuring," in the National Regulatory Research Institute Quarterly Bulletin, Vol. 18, No. 1, Spring 1997, pp. 17-33. 


\section{Solar Portfolio Standard}

The SPS adopted by the ACC directs any electric service provider selling electric power in the state to have a certain percentage of the total retail energy that it sells come from "new" solar resources. The percentage requirements are as follows:

- $\quad$ At least one-half of $1 \%$ of its annual energy sales by January $1,1999$.

- At least $1 \%$ by January 1,2002 . However, the ACC can change this requirement if it takes into consideration the cost of producing solar electricity and the costs of fossil fuels for conventional power plants.

New solar resources are defined as photovoltaic (PV) and solar thermal resources that generate electricity and are installed after January 1, 1997. To meet the required percentage, the solar energy can be purchased or generated. The SPS includes the following provisions:

- Double credits for early adoption: To encourage early adoption of new solar resources, double credits will be awarded for the electricity generated, or caused to be generated, before January 1, 1999, using PV or solar thermal resources installed within Arizona after January 1, 1997. This is a one-time credit that can be applied when competition starts for the companies involved. For example, an early adopter could generate 10 megawatt-hours (MWh) of electricity between January 1, 1997, and December 31, 1998, and receive a one-time credit of $20 \mathrm{MWh}$ toward their solar requirement anytime after December 31, 1998, when retail competition starts for the firms involved.?

- $\quad$ Reporting requirements: Electric service providers shall file a report documenting the output of solar resources, the installation dates of the resources, and the transmission of energy from the resources to Arizona consumers.

- $\quad$ Penalty: Failure to meet the requirements of the SPS is subject to a penalty of $\$ 0.30 /$ kilowatt-hour $(\mathrm{kWh})$. The ACC has the authority to rescind the certificate of convenience and necessity of a service provider who consistently fails to meet such requirements.

- $\quad$ Eligibility of resources installed on customers' premises: PV or solar thermal resources installed at a customer's premises can be counted toward meeting the SPS percentage requirements of the current service provider for those customers.

- Incremental requirements: The SPS requirements are in addition to the renewables resources goals established in ACC Decision No. 58643.

\section{Status}

In Arizona, the SBC will be levied on customers who choose competitive services. Those who choose standard-offer services will pay standard-offer rates, which have already included the costs of their share of the public-benefits programs. The manner in which the SBC is to be calculated will be developed through a workshop process. On April 9, 1997, the working group on "Unbundled Services and Standard Offer" held

${ }^{6}$ ACC, 1996. Section R14-2-1609.

${ }^{7}$ This example is taken from Berry, D., and R.T. Williamson, "Solar Power and Retail Electric Competition in Arizona," Solar Today, March/April, 1997, pp. 34-37. 
its first meeting and has scheduled additional meetings. Once the working group completes its work and issues the guidelines, utilities will file the system benefits charge with the ACC and the commission will review the filings and, where justified, approve the proposed charge and its allocation to customer classes.

For one segment of the renewable energy arena - solar energy - the ACC adopted a separate new mechanism: the SPS. Additional implementation details will be worked out in the workshops. A subcommittee of the Unbundled Services and Standard Offer Working Group has scheduled its first meeting on May 8, 1997, and a workshop on June 2, 1997. 


\section{California}

On December 20, 1995, the Califomia Public Utilities Commission (CPUC) adopted a final policy decision on electric industry restructuring. ${ }^{8}$ The Order states that direct access will be phased in starting on January 1 , 1998 , reaching full access in five years. ${ }^{9}$ To ensure that public-purpose programs will be continued during the transition, the Order adopts a public-goods charge to fund market-transforming energy efficiency, lowincome assistance, and research and development $(R \& D)$ programs. It also requires that electric service providers intending to do business in the state have a minimum percentage of their power supply portfolio in renewable energy.

In early 1996, the CPUC directed the formation of various working groups to address and report on issues relating to the implementation of renewable energy, energy efficiency, and low-income programs. On September 23, 1996, Assembly Bill (AB) 1890 was signed into law. The bill institutes a non-bypassable charge on local distribution services for the provision of public-purpose programs. It also assigns the responsibility of addressing renewables and administering the funds allocated for public-interest research, development, and demonstration (RD\&D) to the Califomia Energy Commission (CEC). At the request of the CPUC, parties in the electric industry restructuring proceeding commented on the reports from the working groups in light of the provisions in $A B$ 1890. Based on this input, the CPUC issued an interim order on public-purpose programs in February $1997,{ }^{10}$ and the CEC subsequently adopted its policy report on $A B 1890$ renewables funding. ${ }^{11}$ The following discussion on the implementation of a system benefits charge for renewable energy, energy efficiency, and low-income programs is based on the CPUC's interim order and the CEC's Renewable Funding report. ${ }^{12}$

\section{Renewable Energy ${ }^{13}$}

$\mathrm{AB} 1890$ directs that $\$ 540$ million be collected from existing investor-owned utility (IOU) customers during 1998-2002 to support existing, new, and emerging renewable electricity generation technologies. Specifically, the funds are to be used to: (1) support the operation of existing and the development of new and emerging in-state renewable resources; (2) support the operations of existing renewable energy technologies that provide

${ }^{8}$ California Public Utilities Commission, Order, Decision 95-12-063, Rulemaking and Investigation on the Commission's Proposed Policies Governing Restructuring California's Electric Service Industry and Reforming Regulation, R.94-04-031 and I. 94-03-032. December 20, 1996.

${ }^{9}$ However, the CPUC decided in May 1997 that direct access become available to all classes of customers-residential, commercial, and industrial-at the same time on January 1, 1998. In processing customers' requests for direct access, utilities are directed to give priority to those who purchase at least $50 \%$ of their loads in the form of renewable energy.

${ }^{10}$ Califomia Public Utilities Commission, Interim Opinion on Public Purpose Programs-Threshold Issues, Decision 97-02-014, Rulemaking and Investigation on the Commission's Proposed Policies Goveming Restructuring Califomia's Electric Service Industry and Reforming Regulation, R.94-04-031 and I. 94-03-032. February 5, 1997.

${ }^{11}$ Califomia Energy Commission, Policy Report on AB 1890 Renewables Funding, March 20, 1997.

${ }^{12} \mathrm{RD} \& \mathrm{D}$ and environmental protection are not covered in this discussion. The former is because $\mathrm{RD} \& \mathrm{D}$ was not formally included in the task description of this project. The latter is because, in the Califomia restructuring process, environmental protection is not specifically included as a public-benefits program that is funded by the public-goods charge.

${ }^{13}$ The description is based on the CEC, 1997. 
fire suppression benefits, reduce landfill materials, and mitigate open-field agricultural buming; and (3) support the operations of existing innovative solar thermal technologies that provide peak generation and reliability benefits.

\section{Administration of the Fund}

The funds designated for renewable energy are to be transferred from the CPUC to the CEC, which will administer these funds. The CEC was directed to develop various recommendations for administrative and expenditure guidelines for using the funds. In developing the recommendations, the CEC assumes that the $\$ 540$ million will be collected evenly during a four-year period at $\$ 135$ million a year.

\section{Proposed Fund Allocation}

Funds will be allocated by accounts and time differentiated. Any under-subscribed funds in a year will roll over in the same account for the following year.

\section{Allocation by Account}

Total available funds will be allocated among the following four primary accounts:

- $\quad$ Existing renewable energy technologies: $45 \%$ of total, equal to $\$ 243$ million.

- $\quad$ New renewable energy technologies: $30 \%$, equal to $\$ 162$ million.

- $\quad$ Emerging technologies: $10 \%$, equal to $\$ 54$ million.

- $\quad$ Customer-side activities: $15 \%$, equal to $\$ 81$ million.

The existing renewable energy technologies account is further allocated to three tiers: first tier, biomass and solar thermal ( $\$ 135$ million); second tier, wind ( $\$ 70.2$ million); third tier, geothermal, small hydro, digester gas, municipal solid waste, and landfill gas (\$37.8 million).

The customer-side account is separated into two subaccounts: customer credit, $\$ 75.6$ million to be awarded for renewable energy direct-access transactions; and $\$ 5.4$ million for consumer information and market building.

\section{Time-Differentiated Allocation}

The allocation will be time differentiated. Funding for existing technologies ramps down over time because of the expectation that they become increasingly competitive, thus reducing the need for funding. New technologies and customer-side activities will ramp up over the years to take advantage of increasing opportunities in later years. Allocation for emerging technologies would remain constant. The specific recommendations are shown in Table 1.

\section{Fund Rollover}

The undersubscribed funds in an account for any period will roll over to the same account in subsequent periods. At the end of 2001, the first 3\% ( $\$ 16.2$ million) of unused funds will be reallocated to emerging technologies. Any remaining funds will be reallocated based on an assessment of the market conditions at that time. 
Table 1. Time-Differentiated Allocation of Renewable Energy Funds

\begin{tabular}{lccccc}
\hline \multicolumn{1}{c}{ Account } & 1998 & 1999 & 2000 & 2001 & Overall \\
\hline Existing Technologies & $57 \%$ & $49 \%$ & $41 \%$ & $33 \%$ & $45 \%$ \\
New Technologies & $24 \%$ & $28 \%$ & $32 \%$ & $36 \%$ & $30 \%$ \\
Emerging Technologies & $10 \%$ & $10 \%$ & $10 \%$ & $10 \%$ & $10 \%$ \\
Customer-Side & $9 \%$ & $13 \%$ & $17 \%$ & $21 \%$ & $15 \%$ \\
\hline
\end{tabular}

\section{Distribution Mechanisms}

There are different mechanisms for distributing the funds for each of the renewable energy technologies. They are as follows:

- $\quad$ Existing technologies will be paid production incentives on a per kilowatt-hour basis. The amount will be determined by the lesser of: (a) target prices minus market clearing prices, (b) available funds divided by generation, or (c) specified production incentive caps. Payments will be made on a monthly basis. Target prices are set to reflect a competitive energy price for the technologies in the three tiers, accounting for their approximate average costs and other revenue streams such as tax credits and capacity payments. The target price decreases from $\$ 0.05 / \mathrm{kWh}$ in 1998 to $\$ 0.035 / \mathrm{kWh}$ for Tier 1 (biomass and solar thermal). It stays constant at $\$ 0.035 / \mathrm{kWh}$ for Tier 2 (wind) and $\$ 0.025 / \mathrm{kWh}$ for Tier 3 (geothermal, small hydro, and digester gas). For Tier 1 , the cap is set at $\$ 0.015 / \mathrm{kWh}$ for 1998 and 1999 and $\$ 0.01 / \mathrm{kWh}$ for 2000 and 2001. Caps for Tiers 2 and 3 are at $\$ 0.01 / \mathrm{kWh}$ in all four years.

- New technologies will be paid production incentives on a per kilowatt-hour basis. Incentives will be awarded based on the competitive bids by potential suppliers, in consideration of two parameters: (a) the cents per kilowatt-hour incentive desired during the five-year distribution period, and (b) estimated annual generation during that same five-year period. Incentives will be awarded to each successive low-cost bidder until the funds from the account are completely allocated. Payments will be made on a monthly basis. Two caps are recommended: first, the cap on new-technology production incentive is $\$ 0.015 / \mathrm{kWh}$; second, no single bidder can be allowed to receive more than $25 \%$ of the available funds allocated to the account.

- The distribution mechanism for emerging technologies will be determined on a project-by-project basis through a request for proposal (RFP) process in early 1998. Actual mechanisms could include interest rate or capital cost buy-down, customer rebates, and other forms of assistance. To maximize the effectiveness of funding support for emerging technologies, seven criteria have been developed to provide funding support for these technologies.

- For the customer credit subaccount, the distribution mechanism is a simple consumption credit paid out through certified providers that deliver power to customers in direct-access contracts. The value of the per kilowatt-hour credit in each payment period will vary and is determined by dividing available funds by the total $\mathrm{kWhs}$ of certified renewable power consumed through qualifying directaccess sales in that period, subject to a cap. 


\section{Certification}

Renewable energy suppliers and providers will need to be certified for eligibility for payments from AB 1890 funds. A self-certification process is proposed. Renewable resource suppliers (generating facilities) will file a standardized form, providing the following information:

1. Name and location of generation facility.

2. Name, address, and telephone and fax numbers of contact person.

3. Description of renewable resource technology used for power generation.

4. Size of facility (nameplate) and capacity of interconnection to grid.

5. Operational date of generating facility (including dates of additions such as repowering).

6. Type of conract with utility (if applicable) and whether and for how long the contract includes fixed energy prices.

7. Percentage of fossil fuel, if any, used in generation (must be $25 \%$ or less).

8. Whether the certification is for accelerated direct access, payment of renewables funds, or both.

Renewable resource providers (those who sell directly to end-use customers, including marketers, aggregators, or suppliers) interested in marketing/brokering power to customers will need to supply the following information:

1. Name, business address, and telephone and fax numbers of company.

2. CPUC provider registration number (if available).

3. Contact person responsible for retail sales.

4. Description of proposed supply portfolio(s).

5. Customer classes to which each resource portfolio is offered.

6. Estimated proportion of power to be obtained form certified renewable sources.

7. List of supplier identification numbers for certified renewable sources.

8. Estimated generation to be obtained from other sources.

9. Whether the certification is for accelerated direct access, payment of renewables funds, or both.

\section{Energy Efficiency ${ }^{14}$}

In Califomia, the CPUC decided to shift the focus of publicly funded energy efficiency programs to those with broader public interests, especially programs with market transformation effects and education efforts that will not be otherwise provided by the competitive marketplace. However, the funding level for energy efficiency programs during the transition period is set legislatively. AB 1890 establishes the following minimum annual funding levels for energy efficiency for the period from 1998 through 2001 for the IOUs in Califomia:

- $\quad$ Pacific Gas and Electric Company: \$106 million per year

- $\quad$ San Diego Gas and Electric Company: \$32 million per year

- $\quad$ Southem Califomia Edison Company: $\$ 90$ million per year for 1998, 1999, and 2000, and a minimum of $\$ 50$ million for 2001.

The CPUC will initially set the above minimum funding levels but has the option of raising them in relation to the scope of activities that may be defined by an Independent Board, which is described below.

\footnotetext{
${ }^{14}$ The discussion in this subsection is based on CPUC, 1997a, Section 4.
} 


\section{Administrative Structure}

The CPUC has established an administrative structure for overseeing the implementation of the markettransformation-type energy efficiency programs during the transition period. The structure will have three basic components: an Independent Board (the decision-making body), a Technical Advisory Committee (TAC), and program administrators.

\section{The Independent Board}

The Independent Board is composed of nine members appointed by the CPUC, including two representatives from the CPUC, one from the CEC, and as many as six members from the public. The Independent Board will develop and oversee contracts with program administrators on specific market-transforming projects. The projects would be selected through a competitive bidding process that would tap the private markets as much as possible. Specific responsibilities of the Independent Board are as follows:

- $\quad$ Appoints a Technical Advisory Committee

- Develops an RFP, setting forth policy and program guidelines for the administrators. The RFP will define the scope of energy efficiency activities funding; provide guidelines for allocating and accounting of money in the fund, including applicable cost-effectiveness criteria; specify how administrative performance should be monitored and evaluated; and contain appropriate contract provisions.

- $\quad$ Proposes changes to the existing demand-side management (DSM) rules that would make them consistent with the CPUC's new emphasis on market transformation

- Selects the program administrators and oversees them in the performance of the contracts.

\section{Technical Advisory Committee}

The TAC is appointed by the Independent Board with wide public representation. To avoid conflict of interest, employees of utilities, the administrators, and other potential contractors of programs and projects should not be on the TAC. The TAC will provide assistance to the Independent Board on technical matters of energy efficiency and DSM, including developing definitions to delineate the scope of projects receiving energy efficiency surcharge funding, and other advice based on technical expertise of the TAC.

\section{Administrators}

There may be one or more administrators for market transformation energy efficiency programs. In the CPUC's view, the duties of the administrator should include the following:

- $\quad$ Assists the Independent Board in selecting various projects

- Verifies program milestones/performance indicators

- $\quad$ Manages any standard offers

- $\quad$ Collects the funds, pays contractors, and manages the bank account

- $\quad$ Provides administrative support to the Independent Board.

\section{Transition to the New Structure}

The target date for the transition to the new administrative structure is January 1, 1998. It is possible that the ransition may not be completed by that date. During the transition, existing energy efficiency services and programs will be continued by the utilities involved. The Independent Board will determine the pace and schedule for the transfer of these functions, including funding, assets, program commitments to the new administrators, and the phase-down of utility involvement in existing energy efficiency programs. 


\section{Low-Income Assistance Programs ${ }^{15}$}

$\mathrm{AB} 1890$ provides that low-income programs shall be funded at no less than the 1996 authorized levels, based on customer need. Existing low-income programs have two components: rate assistance and energy efficiency services. Rate assistance is provided through the Califomia Altemative Rates for Energy (CARE) program. Under CARE, eligible low-income households or group living facilities receive a rate discount of $15 \%$ on electric and gas use. Eligibility criteria for rate discounts are based on income levels of approximately $150 \%$ of the federal poverty levels. A cents-per-kilowatt-hour charge is collected to cover the costs of the CARE program.

Low-income energy efficiency services are currently administered by investor-owned utilities. Although the CPUC recognizes some shortcomings in this structure, it will allow the utilities to continue providing energy efficiency services for the near term. The CPUC favors a statewide surcharge to be administered outside of the utilities. A transition period will be required to accomplish this goal.

As explained below, both components of the low-income assistance program will be administered by the Governing Board.

\section{Administrative Structure}

The CPUC has set up an administrative structure that will ensure that low-income assistance programs are carried out efficiently to meet customers' needs. A Governing Board will be the decision-making body, whereas the day-to-day operations will be carried out by the administrator and contractors. A Low-Income Advisory Committee will be appointed by the Governing Board.

\section{Governing Board}

The Governing Board will oversee the administration process. It will have seven members, two from the CPUC and five from the public. Board members are to be appointed by the CPUC, including the interim acting chair. All members of the Governing Board should have a background in policy development or the provision of energy services for low-income groups.

The low-income rate assistance and energy efficiency services will be administered separately. However, low-income energy efficiency services need to be closely coordinated with energy efficiency programs for the general public. Thus, the Governing Board will coordinate with the Independent Board, which oversees the implementation of general energy efficiency programs.

The Goverming Board will issue an RFP to hire an administrator, and establish the framework for modifying the existing DSM rules. The RFP may be written by a consultant, but will be subject to approval by the CPUC. Funding for the RFP will be fronted by the utilities, which will be reimbursed with interest from funds collected through the low-income program surcharges.

The Governing Board will develop rules conceming conflict of interest and voting rights. The rules will be subject to CPUC approval. Staffing and operating requirements will also be subject to CPUC approval. Any service that the CPUC might provide should be identified by the board.

\footnotetext{
${ }^{15}$ This section is based on CPUC, 1997a, Section 6.
} 


\section{Low-Income Advisory Committee}

The primary responsibility of the Low-Income Advisory Committee is to assist the Governing Board in addressing issues of program design options for CARE and low-income energy efficiency services.

\section{Administrator}

The Governing Board, through a competitive bidding process, will hire an administrator to oversee the lowincome programs. The duties of the administrator will include the following:

- $\quad$ Collects, forecasts, and disburses CARE surcharges

- Verifies customer eligibility, based on current CPUC guidelines

- Makes energy efficiency and education services available

- $\quad$ Processes applications for CARE discounts

- $\quad$ Manages a statewide eligibility database.

The administrator can either provide these services with its own personnel and resources or contract them out.

Maintaining a statewide focus will allow customers to switch providers without having to reapply for assistance. A standard information packet will be developed by the administrator, who will outline the services available to low-income individuals. The administrator will ensure that all low-income services are available in all localities. Guidelines for the development of services will be presented in the RFP. The CPUC stipulates that these services may be either community based or contracted to energy service companies (ESCOs). Utilities will be permitted to respond to the RFP for an administrator, or to contract to provide services. Utilities will not be chosen as the administrator or contractors unless the Governing Board has put in place sufficient safeguards against potential conflicts of interest, market power abuse, and self-dealing. In any case, all funds will be distributed on a competitive basis.

After the new structure is in place, low-income programs for both electricity and gas will be under the control of the administrator. This includes those programs currently administered by Southem Califomia Gas Company. Gas utilities will continue administering their own programs until a non-bypassable surcharge is available to them. During the transition period, the gas utilities will have an option to continue their own lowincome assistance programs or transfer the funds to the Governing Board.

\section{Funding Levels}

The CPUC determined that the 1998 funding levels for low-income assistance program be set at the 1996 level. Total costs for electric low-income programs in 1996 were approximately $\$ 106.9$ million. Only about $58 \%$ of eligible homes received CARE assistance in 1996, and low-income weatherization programs had a saturation rate of $56 \%$ for the same year. Future levels of funding will be set by the Governing Board, using input from the Low-Income Advisory Committee and information obtained from a future customer-needs assessment.

\section{Status}

On March 19, 1997, an administrative law judge's ruling ${ }^{16}$ set forth a detailed schedule for implementing the CPUC's interim decision on public-purpose programs. In conformance with the schedule, the CPUC appointed

\footnotetext{
${ }^{16}$ Public Utilities Commission of the State of Califomia, Administrative Law Judge Ruling: Implementation of Decision 97-02-014, Cases R. 94-04-031 and I. 94-04-032. March 18,1997.
} 
members of both the Independent Board and the Governing Board on April 9, 1997. Organizational meetings were scheduled for April 14-18 and April 21-25, 1997. In addition, the Independent Board and the Governing Board will file governing rules and an RFP for administrator(s), including program design and funding criteria, fund allocation rules, conflict-of-interest provisions, and a sample contract, by October 7, 1997. 


\section{Massachusetts}

On December 30, 1996, the Massachusetts Department of Public Utilities (DPU) issued its plan for restructuring the electric industry in the state. ${ }^{17}$ The plan includes model rules (hereafter referred to as the Rules) and legislative proposals to change state laws towards supporting the DPU's vision of the future for the electric industry. The DPU plans to begin a transition to competitive electricity generation and customer choice in January 1998. Measures were taken to ensure that current public-benefits programs supported by the regulated utilities continue to play a role in the restructured electric industry. The DPU proposed a nonbypassable access charge on each kilowatt-hour sold in Massachusetts. The charge, called the General Access Charge, will be used to

- $\quad$ Fund support for renewable and emerging technologies.

- $\quad$ Continue utility DSM and energy efficiency programs.

- $\quad$ Provide assistance to low-income families.

The DPU also reaffirms its policy of allowing net metering to enhance the likelihood that distributed generation will be implemented where and when appropriate. To continue support in the area of environmental protection, the DPU will rely on a combination of efficient competition, consumer choice, environmentally benign resource options, enhanced consumer information, support for and coordination with environmental regulators at state and federal levels, as well as support for environmental comparability.

\section{Renewable Energy}

A renewables fund will be established and funded through a non-bypassable access charge collected from customers of all distribution companies. The charge will be collected as part of the general access charge. Funds will be distributed to providers of renewable energy to offset some or all of the cost difference between the actual price for power from emerging and renewable energy technologies and the price that customers are willing to pay for power from renewables. Elements of this approach are as follows:

- Renewables are those renewable energy sources or emerging technologies that are relatively immature but have significant potential for commercialization in New England. Renewables include solar and wind power projects, fuel cells, and biomass (limited to dedicated fuel stock cultivation, except wood).

- $\quad$ Beginning January 1,1998 , the charge will be set at $1 \mathrm{mill} / \mathrm{kWh}(\$ 0.001 / \mathrm{kWh})$, to be modified from time to time by the DPU. It is estimated that this will yield an amount equal to $\$ 40$ million annually. ${ }^{18}$

- A renewables collaborative will be formed to address administration of the fund, including selection of an administrator, fund disbursement decisions, and the establishment of a cap on funds provided to any single technology. The collaborative is expected to submit its recommendations to the DPU by July 1, 1997.

- After three years, the DPU will review the results of the renewable fund and reevaluate the need for continued support of renewables commercialization and the appropriate level of funding.

\footnotetext{
${ }^{17}$ Massachusetts Department of Public Utilities, Electric Industry Restructuring Plan: Model Rules and Legislative Proposal, D.P.U. 96-100. December 30, 1996.

${ }^{18}$ MacGregor, T. "System Benefits Charge in Massachusetts," presented at the National Association of Regulatory Utility Commissioners 1997 Winter Committee Meetings, February 23, 1997.
} 
The following provisions also apply to renewables:

- To enable customers to make informed decisions when choosing their power supplies, each distribution company will be required to make all nonproprietary information that it has obtained regarding renewables and emerging energy technologies available to its customers.

- The Rules will permit net metering. Specifically, a customer of a distribution company with an onsite generation source of $30 \mathrm{~kW}$ or less will be allowed to run their meter backward. The customer may also choose to receive a credit from the distribution company equal to the average market price of generation per kilowatt-hour in any month during which there was a positive net difference between kilowatt-hours generated and kilowatt-hours consumed. The rules will also prohibit distribution companies from imposing special fees, such as backup charges and demand charges; additional controls; or liability insurance on net-metering customers as long as the generation source meets the interconnection standards and all relevant safety and power quality standards. Net-metering customers must still pay the minimum charge for distribution service and all charges for each kilowatt-hour delivered by the distribution company in each billing period.

\section{DSM and Energy Efficiency}

The DPU adopted this principle for maintaining DSM programs: During the transition to a competitive generation market, there must be a provision to preserve the DSM infrastructure so that DSM has a meaningful opportunity to compete in a restructured industry. DSM may also have a continuing role in the long term in addressing ongoing market barriers. ${ }^{19}$

\section{Energy Efficiency Plan}

Each distribution company will be required to file a five-year energy efficiency plan at its first conservation charge filing following the effective date of the Rules. A detailed plan for the first two years and a projected plan for the last three years will be required. Subsequently, the distribution company must file a detailed plan for the last three years at least 90 days before the end of the previous two-year period. The plan should include the following:

- An educational component that will provide customers with adequate information about energy efficiency for making informed decisions

- A proposal for supporting regional or national initiatives for market-transforming energy efficiency programs to the extent that such initiatives can provide benefits to the company's customers

- A description of the evolution of the company's DSM programs to market-driven efforts during the years covered by the plan

- A description of evaluation criteria appropriate to the energy efficiency measures and the market transformation initiatives included in the plan

- A proposal for coordinating delivery of energy efficiency services to low-income customers with local Weatherization Assistance Program (WAP) agencies and other appropriate entities that serve lowincome populations in the company's service territory

- $\quad$ Proposed budgets and incentives.

${ }^{19}$ MacGregor, T., "Energy Efficiency After Restructuring in Massachusetts," presented at the National Association of Regulatory Utility Commissioners 1997 Winter Committee Meetings, February 23, 1997. 


\section{Funding}

The costs for providing energy efficiency services will be paid for through the General Access Charge. Details of appropriate budget levels, incentives, and measurement of energy efficiency activities will be determined in a company-specific manner. A collaborative approach to address such issues among stakeholders is encouraged.

\section{Information Requirements}

Each distribution company will be required to make all nonproprietary information that it has obtained regarding energy efficiency technologies, measures, or practices available to its customers. The company will be required to make provisions for customers who want to keep customer-specific energy efficiency information confidential. Each distribution company will file a biennial report on its energy efficiency activities.

\section{Assistance to Low-Income Consumers}

The Rules adopt two approaches to offering assistance to low-income families. They are discussed in the following paragraphs.

\section{Low-Income Customer Tariff}

Distribution companies will be directed to offer a low-income customer tariff that provides a discount for such customers. Specific requirements of the tariff are as follows:

- The level of discount shall be equivalent to that provided by the company as of the effective date of the Rules. Discounts are to be applied only to each company's distribution rates and stranded cost charge. Because the Federal Energy Regulatory Commission (FERC) has jurisdiction over transmission rates, the discount will not be applied to transmission rates.

- $\quad$ Eligibility for the low-income customer tariff will be based on a set of qualifications approved by the DPU. Existing tariff provisions typically specify that a low-income customer must be the head of household or principal wage earner and currently be receiving one form of federal or state assistance to low-income families. Such assistance includes supplemental security income assistance from the Social Security Administration, Aid to Families with Dependent Children, food stamps, or lowincome heating energy assistance.

- $\quad$ Any revenue deficiency resulting from the low-income customer tariff will be allocated to other rate classes using allocation methods approved by the DPU. If these methods raise rate design issues, the DPU will address them on a case-by-case basis.

- The allocated revenue deficiency will be recovered through the General Access Charge.

\section{Weatherization Services to Low-Income Families}

As noted earlier (under DSM and Energy Efficiency), a local distribution company will be directed to coordinate delivery of weatherization services to low-income families with the local entities that operate WAPs. This provision originates from DPU's concern that some market barriers specifically affect lowincome customers, preventing them from purchasing energy efficiency services. Without the low-income weatherization services required by the Rules, such barriers are likely to persist and prevent improvement in the energy efficiencies of the low-income housing stock. 


\section{Environmental Protection}

Recognizing that electricity generation and transmission have major environmental impacts, one of DPU's goals in electric industry restructuring is to ensure that electric service is provided with minimal environmental impacts. The DPU feels that efficient competition in the electric industry should support and further the goals of environmental regulation. DPU's approach to environmental protection under electric industry restructuring is as follows:

- DPU believes that, in order for competition to be full and fair, generating units should be brought under equivalent environmental controls for both old and new power plants; i.e., there should be environmental comparability between new and old plants. However, ensuring such environmental comparability is the responsibility of the environmental regulators, not the DPU. However, DPU would maintain close coordination with environmental regulators.

- The proposed renewables fund will influence the environmental characteristics of the generation resource mix by promoting generation technologies that are more environmentally friendly.

- When registering to participate in retail competition, electric service suppliers should provide information on the sources and environmental impacts of power that they propose to sell to consumers in Massachusetts. The Rules will also require suppliers to provide quarterly reports on fuel sources and emissions characteristics of their power supplies for their entire portfolio of generating resources once electricity starts to flow. Such information would facilitate the decision making of consumers who are interested in purchasing electricity from low-emission sources.

- The DPU recommends that FERC require the independent system operator to collect and disseminate real-time emissions information associated with dispatch of generating units.

- $\quad$ The DPU will continue to support regional efforts to evaluate and ameliorate the regional environmental impacts of electric industry restructuring. Specifically, it will monitor the progress of the Ozone Transport Assessment Group (OTAG), which is charged to address interstate pollutant transport issues.

Note that activities associated with environmental protection are being carried out as part of the DPU's normal operations, and are not separately supported by the General Access Charge.

\section{Status}

In Massachusetts, a non-bypassable access charge, called General Access Charge, will be levied on all customers of a distribution company to fund renewable and emerging technologies, energy efficiency and DSM programs, and assistance to low-income families. For renewable energy, this involves setting up a Renewables Fund, financed initially by a $1 \mathrm{mill} / \mathrm{kWh}(\$ 0.001 / \mathrm{kWh})$ charge, starting on January 1,1998 . The adminis rative details for the operation of the Renewables Fund will be worked out in a collaborative process. The collaborative had an organizational meeting on April 10,1997. With subsequent meetings in May and June, the collaborative expects to submit its recommendations to the DPU by no later than June 30, 1997.

In the case of energy efficiency and DSM, each distribution company will be required to submit a five-year energy efficiency plan, with a detailed plan for the first two years. Such plan should be filed when a distribution company files its first conservation charge after the effective date of the Rules. Costs of programs included in the energy efficiency plan will be funded through the General Access Charge. The details for administering such charge will be determined on a company-specific basis. The DPU encourages collaborative 
efforts to address such issues. Technical fonms were held in April and May 1997 to develop the appropriate cost-effectiveness tests for energy efficiency programs, joint initiatives of energy efficiency programs, and statewide low-income energy efficiency programs.

As for assistance to low-income customers, a distribution company is directed to file a low-income customer tariff with the same level of discount as that provided on the effective date of the Rules. The discounts will be applied to only the distribution rate and the stranded-cost charge, not the transmission charge. Any revenue deficiency resulting from the low-income customer tariff will be collected through the General Access Charge.

For environmental protection, the DPU supports environmental comparability of generation resources of different vintage. It will coordinate with environmental regulators, and require disclosure and quarterly report of fuel sources and emission characteristics of the power supplies of electric service providers.

In mid-May 1997, the DPU approved a settlement agreement for Massachusetts Electric Company that contains a variation of the specifications for the SBC. In this case, a surcharge of $\$ 0.004 / \mathrm{kWh}$ is set for energy efficiency and renewable energy combined. For renewable energy, the charge starts with $\$ 0.00025 / \mathrm{kWh}$ in $1998, \$ 0.00055 / \mathrm{kWh}$ in $1999, \$ 0.00085 / \mathrm{kWh}$ in 2000 , and $\$ 0.00125 / \mathrm{kWh}$ in 2001 . As the allocation for renewables increases, that for energy efficiency decreases. A similar settlement agreement for Eastem Utilities is also pending before the DPU. ${ }^{20}$

${ }^{20}$ This information is based on a telephone conversation with Theo MacGregor of the DPU on May 29, 1997. 


\section{New York}

The New York Public Service Commission (NYPSC) adopted a plan to restructure the electric industry on May 20, $1996 .{ }^{21}$ It directed the implementation of wholesale competition by early 1997 and retail competition by early 1998. In the process, the NYPSC affirmed its responsibility in ensuring that electric service is provided safely, cleanly, and efficiently. In its view, "the responsibility may entail continuing specific measures to preserve certain programs such as energy efficiency, research and development, environmental protection, and low-income programs beyond what competitive markets provide. ${ }^{122}$ It further adopted a system benefits charge for such public-policy programs. The NYPSC stated the following:

A system benefits charge would provide a funding source during the transition, and possibly over the long term, for public policy initiatives that are not expected to be adequately addressed by competitive markets. It would be designed to ensure that the cost of carrying out these public policy initiatives was fairly allocated across most, if not all, users of the power distribution system, and recovered in a competitively neutral manner. Initially, the system benefits charge would be set at approximately the level of current utility expenditures, with the expectation that these charges will be closely scrutinized with respect to their impacts on rates. Programs funded in this way, along with the innovative programs likely to be developed by energy service companies, provide ample reason to be confident, as we are, that cost-effective energy conservation measures, including demand-side management, will flourish in the new environment. We anticipate the levels of energy efficiency programs accomplished in this way will be higher than existing levels.

In light of the potential benefits, a system benefits charge should be put in place during the transition to retail competition. The use of a system benefits charge should be revisited sometime after retail competition has commenced to determine whether the level of these programs is sufficient and whether the continued use of a system benefits charge is required.

To ensure that funding is provided consistent with our policy and that any fund is administered properly, we will continue to oversee these programs. ${ }^{23}$

The NYPSC is in the process of developing the implementation procedures and guidelines with respect to the SBC. On April 1, 1997, the NYPSC staff filed a position paper on issues pertaining to such matters. ${ }^{24}$ The following information is based on the NYPSC staff proposal.

\section{Programs Covered}

Consistent with the NYPSC order in Opinion No. 96-12, the NYPSC staff divided the programs to be supported by the SBC funds into the following four categories:

\footnotetext{
${ }^{21}$ New York Public Service Commission, Opinion and Order Regarding Competitive Opportunities for Electric Service, Opinion No. 96-12, Cases 94-E-0952. In the matter of competitive opportunities regarding electric service. May 20, 1996.

${ }^{22}$ NYPSC, 1996. p. 27.

${ }^{23}$ NYPSC, 1996. pp. 56-57.

${ }^{24}$ NYPSC, System Benefits Charge: Staff Position Paper, Case 94-E-0952. In the matter of competitive opportunities regarding electric service. April 1, 1997.
} 
- $\quad$ Energy efficiency programs and services.

- Public-benefits research, development, and demonstration projects related to energy service, generation or energy storage, the environment (including monitoring and assessment), and renewables.

- $\quad$ Low-income, energy efficiency, and energy management pilot programs.

- Environmental protection programs that go beyond compliance with law or permit requirements, including programs designed to monitor and mitigate environmental impacts of electric industry restructuring.

All of these programs must be approved by the NYPSC. Specific activities or programs included in each category are noted below.

\section{Energy Efficiency Services Programs}

Energy efficiency programs may include those aimed specifically at developing or promoting the development of the energy services market, increasing choice, or bringing customers together with ESCOs. They can also cover programs that educate the public or ESCOs on energy efficiency options and on assessing service options and prices offered by ESCOs. In addition, programs that could permanently transform the market for energy-efficient products and services or reduce market barriers, rather than simply achieve immediate or customer-specific savings, will also be included. Finally, programs that ensure the quality or measure the achievement of SBC activities will be covered.

\section{Research and Development Programs}

In the area of R\&D, the programs will include energy efficiency, the environment, renewable resources, and other types of public-benefits research that are unlikely to be continued by the private sector during the transition to competition. In NYPSC staff's view, the focus should be on pollution monitoring and control, and the introduction of innovative technologies in the production and use of electricity, including renewables. Such programs should directly benefit the ratepayers or be of clear economic or environmental benefit to the people of New York on a statewide basis and may not be otherwise accomplished.

\section{Low-Income Programs}

Such programs should be designed to leverage funds from other state and federal assistance programs and to create local partnerships among utilities, weatherization providers, community action agencies, and other service entities and programs. There should be consumer/energy education and credit/budget counseling. The programs should respond to regional differences; target diverse low-income groups, including customers with high energy bills; and show great potential for energy savings.

\section{Environmental Protection}

The environmental protection programs are those approved by the NYPSC and not otherwise required by law, including activities associated with environmental monitoring and assessment. 


\section{Activities not Supported by the SBC}

The staff proposal was very specific about the activities that are not to be supported by the SBC:

- $\quad$ Activities that are undertaken as part of the regulated transmission and distribution (T\&D) utility's obligation to serve, such as energy efficiency, renewable energy, or distributed generation undertaken by the T\&D utility in lieu of constructing new generation facilities; T\&D-related R\&D efforts; costeffective programs to reduce uncollectibles; and T\&D-related environmental protection programs.

- A collection mechanism for the recovery of stranded costs, above-market generation taxes, state and federal agency assessments, other costs of complying with regulation, and uncollectibles and other obligation-to-serve costs.

- Programs and activities in non-T\&D sectors undertaken to comply with state and federal environmental laws or permit requirements.

\section{Funding Level}

Consistent with the NYPSC's order (Opinion No. 96-12) to achieve greater rate equity across utility companies and to address the NYPSC's potential rate impact of imposing the SBC, the NYPSC staff proposes to set the SBC at the lower of $1 \mathrm{mill} / \mathrm{kWh}(\$ 0.001 / \mathrm{kWh})$, or the rate sufficient to collect the utility's 1995 spending level for energy efficiency, public-benefits research and development, and low-income programs. Calculations by the NYPSC staff indicate that this would yield about $\$ 97.6$ million a year. This funding level does not provide for environmental protection activities. If such activities are identified for SBC funding, the funding level needs to be increased.

\section{Project Selection and Fund Allocation}

The NYPSC staff proposes the following process and principles for fund allocation and project selection:

- The NYPSC staff proposes that the NYPSC institute a proceeding to develop a two-year plan for the selection and funding of specific projects to be supported by the SBC fund, or to develop the criteria to be used in the selection of the SBC projects. In the meantime, utilities will continue their existing approved programs.

- $\quad$ Prior to the expiration of the initial two-year SBC plan, the NYPSC would institute another proceeding to identify programs and projects that were or were not addressed by the competitive market and determine the need for continuing ratepayer funding of the public-policy programs.

- $\quad$ The NYPSC staff also proposes a guiding principle for deciding whether specific future programs should be funded by the SBC: SBC programs should create conditions where the competitive delivery of products and services thrive so that SBC funding for these activities is no longer required.

- $\quad$ The SBC funds should largely be expended in the service territory from which they are collected. However, a portion of the SBC funds may be allocated to statewide programs that would provide greater benefits than if they were separately implemented by individual utilities.

\section{Fund Administration}

Utilities and other independent contractors may bid for the contract for fund administration. Utilities have gained expertise during the past decade or so in implementing a number of public-policy programs. Hence, 
there is some support for allowing utilities to bid for the task of administering the SBC fund. On the other hand, there are concerns about conflicts of interests and anticompetitive practices with a utility SBC fund administrator. Thus, if a utility was selected to administer the SBC funds, some additional safeguards would need to be established to prevent anticompetitive practices and other abuses.

The NYPSC staff favors a hybrid approach in which T\&D utilities will continue to administer programs that they are more efficient in implementing and, at the same time, a separate fund administrator will manage the statewide programs.

\section{Fund Administrator}

The duties of the fund administrator include assembling an advisory committee to advise the fund administrator on matters relating to program design, implementation, monitoring, and quality control; developing and issuing a request for proposals or standard offers; selecting contractors for implementing programs and providing services; as well as collecting funds from utilities, managing project funds, verifying program milestones, and paying contractors.

\section{Commission Oversight}

The NYPSC would exercise its oversight responsibilities in the matter. Through the planning proceeding proposed by the staff, as part of developing the two-year plan for implementing the SBC, the NYPSC would adopt criteria and guidelines for the following:

- Guidelines for determining those programs and projects that are adequately funded in competitive markets and those that are not likely to be funded in competitive markets.

- Guidelines to ensure that, when the utilities play a role in implementing SBC programs, they do not use these programs for anticompetitive purposes.

- Guidelines focusing SBC-funded programs on those markets and projects that are likely to have the greatest returns for the investment or that can lead to market solutions.

- Guidelines for desirable cost efficiency and payback period goals for the types of public-policy programs covered with SBC funding.

- Goals for timely and efficient delivery of program services.

- $\quad$ Requirements for ongoing program review and evaluation, including market research to identify appropriate program opportunities.

In addition, a set of policy guidelines for the fund administrator would be established conceming conflicts of interest, market power abuse, and self-dealing for all potential bidders, including the regulated T\&D utilities. If a regulated utility is selected as the fund administrator, additional safeguards may be included. The NYPSC could also impose appropriate restrictions on the transactions and other activities between the regulated utilities and their unregulated affiliates in energy efficiency and other products. The NYPSC may also put into place performance incentives and use a competitive bid process for selecting contractors for specific projects and programs. Finally, the NYPSC would need to closely monitor the operations of a utility's unregulated ESCO affiliates to enforce the provision requiring that transactions among affiliated companies be kept at arm's length. 


\section{Status}

The above descriptions of the details of New York's SBC are based on the proposal of the NYPSC staff. Other parties in the proceeding (Case 94-E-0952) filed their initial comments on April 1,1997. Reply papers were filed on April 17, 1997. The NYPSC initially expected to issue its decision on the SBC by June 10, 1997. ${ }^{25}$ Subsequent interim rulings by the NYPSC have resulted in a delay of the decision until late summer or early fall. ${ }^{26}$

${ }^{25}$ Lee, J. A., "Ruling Modifying Schedule," administrative law judge's procedural ruling, Case 94-E-0952 in the matter of competitive opportunities regarding electric service, NYPSC, March 21, 1997.

${ }^{26}$ This is based on a telephone conversation with Martin Insogna of the NYPSC on May 30, 1997. 


\section{Rhode Island}

The Rhode Island Utility Restructuring Act of 1996 (the Act) was signed by the governor on August 7, 1996. The Act phases in retail access to electricity starting on July 1, 1997. Full retail access will be reached by July 1, 1998, or sooner if retail access becomes available to more than $40 \%$ of New England. To address public-policy programs, the Act provides for a charge to be collected at the electricity distribution level to fund DSM and renewable resources. The Act also directs that low-income discounts be continued and the costs be charged to distribution rates applied to all other customers. In response to environmental protection, the Act essentially addresses power plants located outside of the state.

\section{Demand-Side Management and Renewable Energy}

In Rhode Island, funding for DSM and renewable energy is specified by the Act as follows:

- Starting on January 1,1997 , a charge of $2.3 \mathrm{mills} / \mathrm{kWh}(\$ 0.0023 / \mathrm{kWh})$ delivered will be included in a distribution company's rates to fund DSM programs and renewable energy resources. It is estimated that total funds collected are more than $\$ 18$ million a year. The charge will be applied for five years.

- The Rhode Island Public Utility Commission (the Commission) will determine how the funds will be allocated between DSM and renewable energy.

- During the five-year period, the Commission can increase the funds for DSM and renewable energy after holding public hearings, and adjust the per-kilowatt-hour charge accordingly, after separate hearings.

- After five years, the Commission will make further decisions concerning the level of this charge.

- Renewable energy resources are defined as power generation technologies that produce electricity from wind energy, small-scale (less than 100-MW) hydropower plants that do not require the construction of new dams, solar energy, and sustainably managed biomass.

- $\quad$ Fuel cells are considered to be a technology that improve energy use efficiency and are included in the DSM programs.

\section{Low-Income Assistance}

The Act declares that in a restructured electric industry the same protection currently afforded low-income customers shall continue. Specifically, it directs that:

- Distribution companies continue the special rates for low-income customers that are in effect when the Act becomes effective.

- The cost of the discounts can be included in the rates of electric distribution companies.

- With the Commission's approval, electric distribution companies can also implement additional programs offering assistance to low-income customers.

\section{Environmental Protection}

The Act states that, because power plants in Rhode Island already have low emissions relative to their counterparts in other states, utility restructuring plans are not required to address in-state air emission 
reductions. However, the Act does place a requirement on wholesale power suppliers who will be receiving contract termination fees paid through transition charges from Rhode Island utilities and who operate fossilfueled power plants in other states that do not meet applicable air emission standards as of December 31, 1995. According to the Act, such wholesale power suppliers shall work with environmental officials in the states where their power plants are located to develop a plan for reducing nitrogen oxides, sulfur dioxide, and particulate emissions from such plants. This shall be done through retirements, replacements, controls, or offsets, or any combination of the above. The objective should be to reduce the emissions of their overall portfolio of power plants to levels applicable to new electric generating facilities in effect in the state or states where the plants are located as of January 1,1996. The plans shall be implemented in connection with electric industry restructuring in the state or states where the generating facilities are located. In addition, the Act declares that it is state policy to encourage states that have fossil-fueled electric-generating plants that produce air emissions that affect Rhode Island air quality to reduce such emissions. This is to be done over time to levels that would allow Rhode Island to cost effectively comply with environmental standards.

\section{Status}

Utilities in Rhode Island began collecting an SBC on January 1, 1997. Existing energy efficiency collaboratives for individual utilities continue to help guide the utilities in implementing energy efficiency and DSM programs, with a new focus on market-transforming programs. A new statewide collaborative on renewable energy was set up. The collaborative issued an RFP and selected a contractor to conduct a study and advise on renewable energy issues. Of the funds collected through the distribution charge, $\$ 210,000$ was allocated to renewable energy in 1997, a sum that is expected to increase in subsequent years. 


\section{Wisconsin}

In February 1996, the Public Service Commission of Wisconsin (PSCW), following nearly two years of informal and formal investigations, presented a report to the state legislature on its strategy to restructure the electric utility industry in Wisconsin. ${ }^{27}$ The report targets the year 2000 for the start of retail competition, which will be implemented only if all necessary conditions for sustaining competition are in place. It includes a 32-step work plan to achieve increased competition and customer choice. Step No. 6 of the work plan involves establishing a Public-Benefits Policy Advisory Board and conducting implementation and coordination activities concerning public-benefits programs. This reflects the PSCW's intention to preserve public benefits during restructuring by continuing conservation programs, encouraging the use of renewable resources, implementing green pricing, and continuing low-income programs.

\section{Funding Mechanism}

In March 1996, the PSCW opened Docket 05-BU-100 to address such public-benefits issues. Stakeholders then developed proposals to implement details and procedures. In late January 1997, four proposals were presented to the PSCW: one by a coalition of utilities and consumer and public interest groups; another by major electric utilities in the state; the third by a gas company; and the fourth, with a focus on low-income programs, by a coalition of community action groups. Parties in the docket then presented comments on the proposals to the PSCW.

On March 27, 1997, after considering all the inputs into the process, the PSCW defined a plan to preserve the public-benefits programs. The plan proposes the creation of two advisory councils: one to deal with energy conservation, renewables, and environmental research; the other to address issues on low-income assistance. The plan also proposes funding levels for the public-benefits programs.

Initially, the PSCW did not determine the funding mechanism, but did direct staff to develop competitively neurral funding mechanisms. ${ }^{28}$ The PSCW subsequently decided to impose an annual fee on a Btu equivalency basis on all gas and electric service providers, whether they are utilities, power marketers, or others. The annual fee will be based on the annual sales of the service providers in one year. The fee will be paid in 12 equal installments in the following year. ${ }^{29}$ Because the fee is not directly assessed on end-use customers, it is not an SBC per se. However, to the extent that the burden of the fee may be transferred to the customers through higher prices, it shares the same characteristics of an SBC.

\footnotetext{
${ }^{27}$ Public Service Commission of Wisconsin, Electric Utility Restructuring in Wisconsin, Report to the Wisconsin Legislature, February 22, 1996.

${ }^{28} \mathrm{PSCW}$, "PSC Recommends Plan That Protects Customers and Environment Under Electric Deregulation," news release, March 27, 1997.

${ }^{29}$ This information is derived from a telephone conversation with Gary Mathis, Public Service Commission of Wisconsin, May 21, 1997.
} 


\section{Energy Conservation, Renewables, and Environmental Research ${ }^{30}$}

\section{Energy and Environmental Public-Benefits Advisory Council}

The Energy and Environmental Public-Benefits Advisory Council, to be composed of 11 members, will be organizationally attached to the PSCW for a seven-year term. It will implement energy efficiency programs now run by utilities and work to remove market barriers for private-sector energy efficiency activities. The Council will also promote renewable energy development and environmental research. More specifically, its scope of activities will include the following:

- $\quad$ Development of DSM markets

- Delivery of conservation services

- $\quad$ Research, development, and demonstration of DSM

- $\quad$ Consumer education on benefits and market availability of DSM and renewable energy

- $\quad$ Promotion of customer-based renewable technologies

- $\quad$ Research, development, and demonstration of wind, biomass, and solar energy.

An administrator will be hired to oversee these activities.

\section{Funding Levels}

The PSCW proposes to set the following annual funding levels: energy conservation programs, $\$ 100$ million; renewable energy programs, $\$ 5$ million; environmental research, $\$ 2$ million. The $\$ 100$ million for energy conservation represents an increase of $\$ 25$ million from the current level in order to restore funding to energy efficiency initiatives and to finance the transition of DSM programs from utilities to private entrepreneurs under competitive situations. The $\$ 5$ million for renewables is an increase from the current $\$ 0.5$ million level.

\section{Low-Income Programs}

\section{Low-Income Public-Benefits Advisory Council}

The PSCW will recommend that the legislature set up the Low-Income Public-Benefits Advisory Council as a permanent entity under the Department of Administration. It will also have 11 members, and will work to protect low-income utility customers and promote DSM activities. The specific responsibilities of the council will cover the following:

- Low-income weatherization and energy efficiency programs

- $\quad$ Early identification programs

- Low-income energy-bill-paying assistance

- $\quad$ Proactive and crisis management

- Low-income research and development.

An administrator will be retained to manage these activities. Minimum service levels and eligibility criteria will be established by the council and the administrator. These levels will not be fixed, but will be subject to statutory criteria.

\footnotetext{
${ }^{30}$ The descriptions in the remainder of this section are based on the following sources: PSCW, 1997; Electric Utility Week, 1997; and separate telephone conversations with Gary Mathis and Nancy Korda of the PSCW staff, April 21 and 23, 1997.
} 


\section{Proposed Funding}

The PSCW will propose that the funding level for low-income programs be initially set at $\$ 105$ million a year. The Low-Income Advisory Council will assess the needs of the low-income customers every two years. The funds will come from both state and federal sources. Two federal programs-the Low-Income Home Energy Assistance Program and the Low-Income Weatherization Assistance Program-will contribute a combined $\$ 46$ million. The PSCW has yet to determine exactly how the state will collect its $\$ 59$ million share, which is more than 2-1/2 times the current utility spending of $\$ 22$ million on low-income assistance.

\section{Status}

The proposals outlined above require legislative actions. The PSCW will present these public benefits proposals and related policy recommendations to the legislature in May 1997 for legislative action. The framework and funding should be in place for 1999 activities. 


\section{References}

Arizona Corporation Commission. 1996. Opinion and Order, Decision No. 59943, Docket No. U-000094-165, in the matter of the competition in the provision of electric services throughout the state of Arizona. December 1996.

Berry, D.; Williamson, R.T.; Clark, K. 1997. "Staff Discussion of the Proposed Rule on Electric Industry Restructuring." National Regulatory Research Institute Quarterly Bulletin; Vol. 18, No. 1, Spring 1997, pp. 17-33.

Berry, D.; Williamson, R.T. 1997. "Solar Power and Retail Electric Competition in Arizona." Solar Today; March/April 1997, pp. 34-37.

California Energy Commission. 1997. Policy Report on AB 1890 Renewables Funding. March 20.

California Public Utilities Commission. 1996. Order, Decision 95-12-063, Rulemaking and Investigation on the Commission's Proposed Policies Goveming Restructuring California's Electric Service Industry and Reforming Regulation, Cases R.94-04-031 and I. 94-03-032. December 20.

California Public Utilities Commission. 1997. Interim Opinion on Public Purpose Programs-Threshold Issues, Decision 97-02-014, Rulemaking and Investigation on the Commission's Proposed Policies Governing Restructuring California's Electric Service Industry and Reforming Regulation, Cases R.94-04-031 and I. 94-03-032. February 5.

California Public Utilities Commission. 1997. Administrative Law Judge Ruling: Implementation of Decision 97-02-014, Cases R. 94-04-031 and I. 94-04-032. March 18.

Electric Utility Week. 1997. "Wis. PSC Sets Ambitious Funding Levels for Renewables, DSM, Social Programs," April 14, pp. 16-17.

Insogna, M. 1997. Telephone conversation. May 30.

Korda, N. (PSCW). 1997. Telephone conversation. April 23.

Lee, J.A. 1997. "Ruling Modifying Schedule," administrative law judge's procedural ruling, Case 94-E-0952 in the matter of competitive opportunities regarding electric service, New York Public Service Commission. March 21.

MacGregor, T. 1997. "Energy Efficiency After Restructuring in Massachusetts," presented at the National Association of Regulatory Utility Commissioners 1997 Winter Committee Meetings. February 23.

MacGregor, T. 1997. "System Benefits Charge in Massachusetts," presented at the National Association of Regulatory Utility Commissioners 1997 Winter Committee Meetings. February 23.

MacGregor, T. 1997. Telephone conversation. May 29.

Massachusetts Department of Public Utilities. 1996. Electric Industry Restructuring Plan: Model Rules and Legislative Proposal, D.P.U. 96-100. December 30.

Mathis, G. (PSCW). 1997. Telephone conversation. April 21 and May 21. 
New York Public Service Commission. 1996. Opinion and Order Regarding Competitive Opportunities for Electric Service, Opinion No. 96-12, Cases 94-E-0952. In the matter of competitive opportunities regarding electric service. May 20.

New York Public Service Commission. 1997. System Benefits Charge Staff Position Paper, Case 94-E-0952. In the matter of competitive opportunities regarding electric service. April 1.

Public Service Commission of Wisconsin. 1996. Electric Utility Restructuring in Wisconsin, Report to the Wisconsin Legislature. February 22.

Public Service Commission of Wisconsin. 1997. "PSC Recommends Plan That Protects Customers and Environment Under Electric Deregulation," news release. March 27.

Rhode Island General Assembly. 1996. The Utility Restructuring Act of 1996. 96-H 8124B. August 7.

Utah Public Service Commission. 1996. Amended Order Establishing Investigative Docket, Docket No. 96-999-01. In the matter of the Commission's notice of inquiry: Changes in the structure of the electric utility industry and appropriate state regulatory responses. January 31. 


\section{REPORT DOCUMENTATION PAGE}

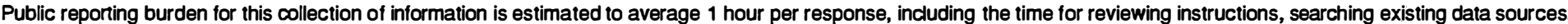

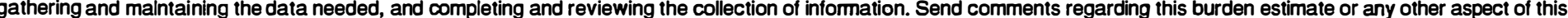

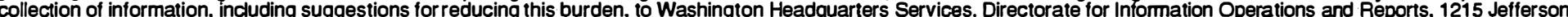

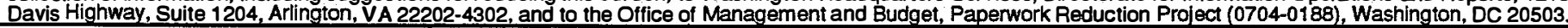
1. AGENCY USE ONLY (Leave blank)
2. REPORT DATE July 1997
3. REPORT TYPE AND DATES COVERED technical

4. TITLE AND SUBTITLE

State Approaches to the System Benefits Charge

5. FUNDING NUMBERS 07964603

6. AUTHOR(S)

Jeffrey M. Fang

7. PERFORMING ORGANIZATION NAME(S) AND ADDRESS(ES)

National Renewable Energy Laboratory REPORT NUMBER

1617 Cole Boulevard

TP-460-22852

Golden, Colorado 80401-3393

10. SPONSORING/MONITORING AGENCYREPORT NUMBER
9. SPONSORINGMONITORING AGENCY NAME(S) AND ADDRESS(ES)

U.S. Department of Energy

1000 Independence Ave., SW

Washington, DC 20585

11. SUPPLEMENTARY NOTES 12a. DISTRIBUTION/AVAILABILITY STATEMENT

National Technical Information Service

U.S. Department of Commerce

5285 Port Royal Road

Springfield, VA 22161 12b. DISTRIBUTION CODE

UC 1321

13. ABSTRACT (Maximum 200 words)

This report documents the consideration and implementation of a non-bypassable system benefits charge in six states through mid-May 1997. The system benefits charge is being established to sustain important public-policy programs during the electric industry restructuring process. The states covered include Arizona, California, Massachusetts, New York, Rhode Island, and Wisconsin. The issues faced by the six states are the system benefits charge in general; surcharge rate or funding levels; administrative structure and procedures; and actions, guidelines, and principles by program area.

14. SUBJECT TERMS

electric industry restructuring; system benefits charge; public-policy programs

15. NUMBER OF PAGES

42

16. PRICE CODE
17. SECURITY CLASSIFICATION OF REPORT

unclassified
18. SECURITY CLASSIFICATION OF THIS PAGE unclassified
19. SECURITY CLASSIFICATION OF ABSTRACT unclassified
20. LIMITATION OF ABSTRACT

UL

NSN 7540-01-280-5500

Standard Form 298 (Rev. 2-89) Prescribed by ANSI Std. Z39-18 